\title{
SECURITISATION, TRANSPARENCY AND FAILURE RISK
}

\author{
Patricia C. O'Brien ${ }^{1}$ \\ University of Waterloo
}

\begin{abstract}
$\mathrm{B}$ anks and other financial companies use securitisation to redistribute risk and increase liquidity by pooling and selling assets. This paper reviews the typical set-up of a securitisation and its potential benefits and risks, including the tendency to concentrate risk in positions retained by the sponsor. The paper illustrates how the accounting for these transactions facilitates this risk concentration and impedes transparency. It discusses some academic evidence on securitisations and the role these complex transactions played in the recent financial crisis and in Ireland's banking sector afterwards.
\end{abstract}

\section{INTRODUCTION}

In Ireland and elsewhere, the recent financial crisis triggered the failure of prominent financial institutions and required massive government intervention to prevent system-wide collapse. Figure 1 illustrates the crisis, plotting the share prices of three of Ireland's major banks (left vertical scale) and the Financial Times 100 index (right vertical scale) from January 2003 through March 2010. The Irish government nationalised the scandal-plagued Anglo Irish Bank in January 2009, while Allied Irish Banks and the Bank of Ireland survived at much reduced valuations after receiving $€ 7$ billion in relief from Irish taxpayers in February 2009.

In a comprehensive discussion of the crisis in Ireland, Connor, Flavin and O'Kelly (2010) conclude that securitisations played little or no role in the Irish financial turmoil. Most commentators agree, however, that these structured transactions played a substantial role in the genesis of the crisis in the United States (US) (see, for example, Acharya, Cooley, Richardson and Walter (2009) and papers cited therein). This paper describes the economic substance and accounting form of typical 
FIGURE I: BAILED-OUT IRISH BANKS AND FTSE- I 00, JAN 2003 - MAR 2010

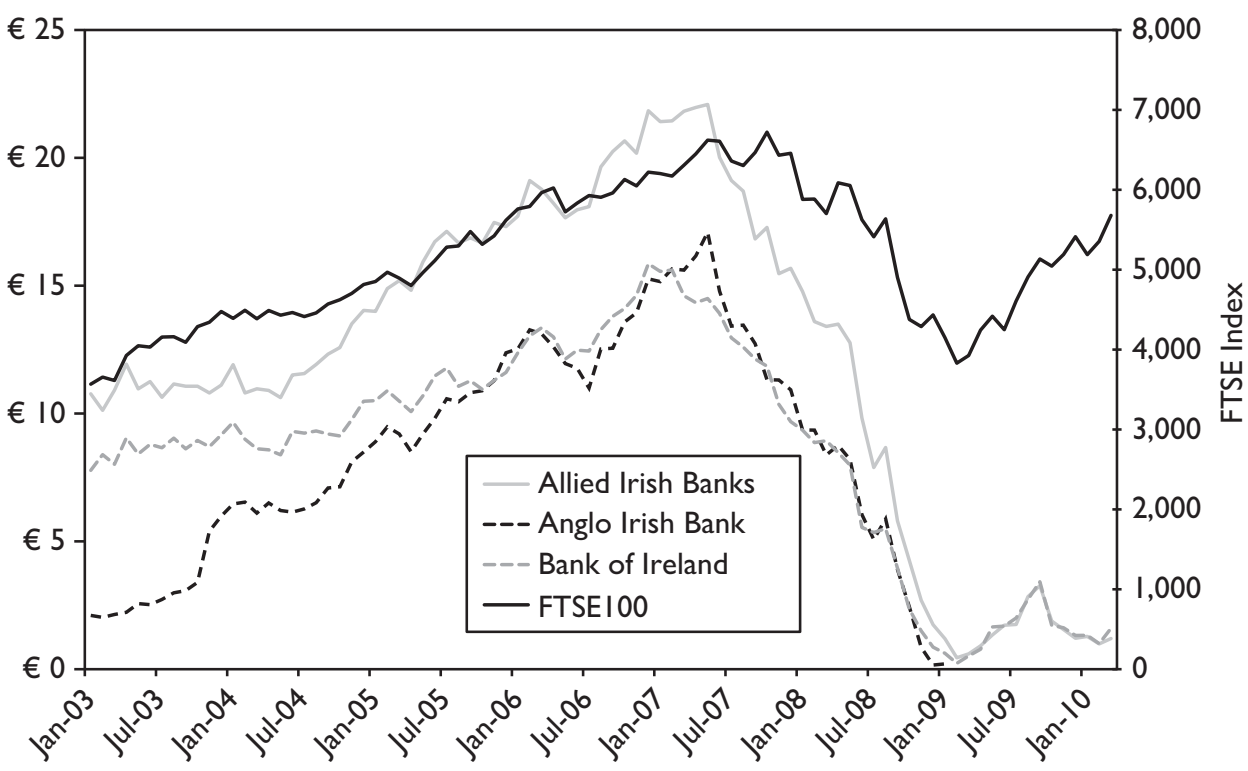

Data source: Yahoo! Finance

securitisations, and explains how the accounting results in a loss of transparency that foils both formal and informal regulatory mechanisms. It reviews academic studies that demonstrated, before the crisis took hold, the distortive effects of securitisations' off-balance-sheet status. The paper provides data to show why Ireland ought not be entirely complacent about these transactions, and concludes by offering views on how to account correctly and prudently for securitisations.

\section{SECURITISATION - A BRIEF REVIEW}

Securitisations allow the sponsor, typically a bank or other financial company, to accelerate cash realisation from financial assets like mortgages. For brevity's sake, this paper refers to the sponsor as a bank and the underlying financial assets as home mortgages, though myriad variations exist. Figure 2 illustrates a securitisation. The bank lends to homeowners, whose homes stand as collateral for and whose wages will repay the mortgages. The bank then takes a pool of mortgages and transfers them to an entity created specifically for this purpose, called a 'special purpose vehicle' or SPV, in exchange for cash. The SPV raises cash by issuing securities to investors. The SPV has no other operations; its sole, special purpose is to issue securities funded by the bank's transferred loan portfolio. Typically, by design at least one of the SPV's securities is of very high credit quality, rated AAA by virtue of receiving the most secure and stable cash flows from the mortgage pool. 
FIGURE 2: SECURITISATION SCHEMATIC

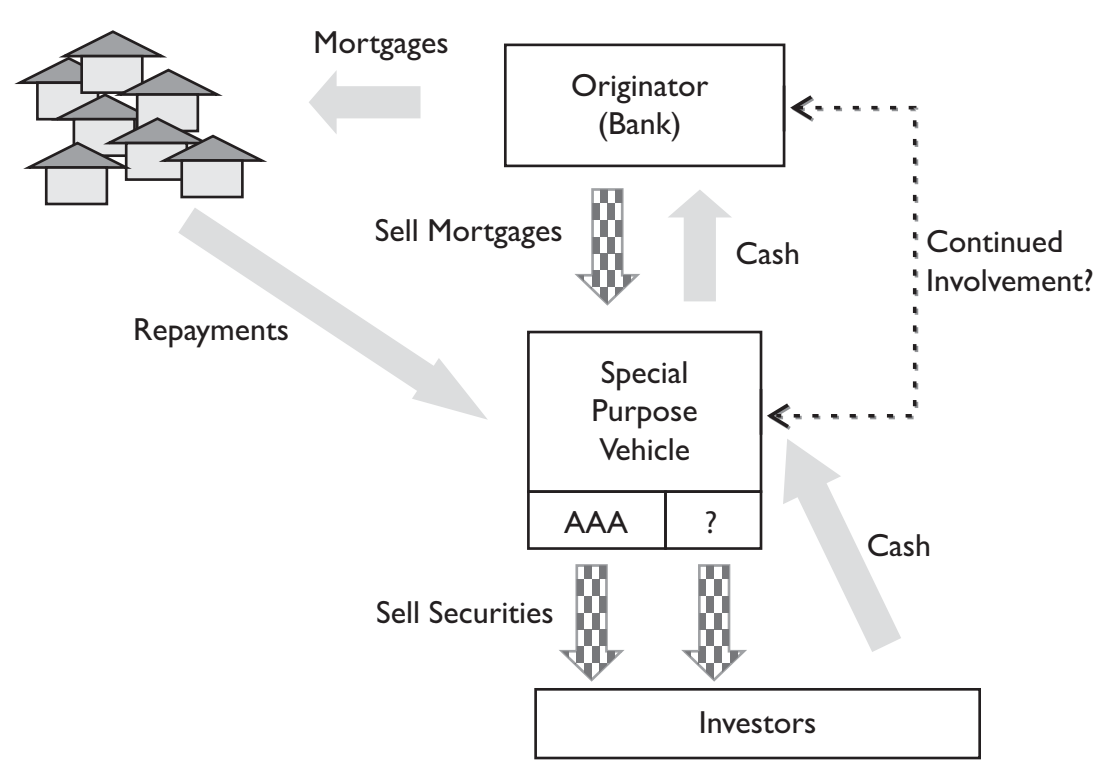

Creating these low-risk, premium tranche securities necessarily concentrates the risk of the mortgage pool in the other claims on the pool.

Advantages of securitisation include allowing the bank to diffuse some of its risks to other financial institutions or to investors, and increasing the supply of credit in the economy. Some believe that undiversified risks, such as the specific geographic risks of a local housing market, aggravated the US Savings and Loan crisis of the 1980s (see, for example, Kormendi, Bernard, Pirrong and Snyder, 1989; Loutskina and Strahan, 2011). If a bank can sell its local risks, and in turn buy unrelated risks from other banks, then it can lower its overall risk through diversification. Securitisations also allow banks to make new loans sooner, effectively increasing the supply of credit by accelerating cash recovery from long-term lending. The disadvantages of securitisation include the concentration of risks in lower-tier securities, mentioned above, along with creation of opaque structures that can evade regulatory scrutiny and capital requirements, as will be discussed in more detail below.

Because the SPV has no business activity, its value and risks derive entirely from the pool of assets transferred from the originating bank, along with any enhancements that it can purchase or the bank can provide. Originators employ a variety of mechanisms for ensuring the highest possible credit rating for at least one tranche of the SPV's securities. These include over-collateralisation, implicit or explicit guarantees from the originating bank and credit default insurance.

Banks need not use securitisation to distribute entity-specific risks or accelerate cash recovery from financial assets. They can, for example, sell whole loans or loan portfolios to other entities, without creating new securities or SPVs. Alternatively, banks can borrow, pledging the loan portfolio as collateral. The accounting for these two alternatives, described below, makes transparent the risks and rewards held by 
the bank. That transparency is, one suspects, the primary reason that securitisation replaced these alternatives. The following simple example contrasts the three alternatives, namely sale without recourse, collateralised borrowing, and securitisation, to illustrate how the accounting for securitisation obscures its substance.

\section{EXAMPLE: SECURITISATION VERSUS LOAN SALES OR SECURED BORROWING}

The example illustrated in Table 1 begins with an extremely simplified bank balance sheet. The bank holds $€ 100$ in loans, capitalised with $€ 90$ in borrowing (including deposits) and $€ 10$ of owners' equity. With a 10 per cent ratio of capital to assets, this bank is well capitalised. The bank wishes to convert the loan portfolio to cash more quickly than waiting for the borrowers to repay, so that it can make additional new loans. For simplicity, the example ignores the bank's earning activity outside of the sale of loans, to focus on its balance sheet. Because the bank seeks to raise cash more quickly than the loans' repayment period, and its earning from interest on loans would take place over that same time frame, this simplification is innocuous.

TABLE I: BALANCE SHEET COMPARISON OF NON-RECOURSE SALE, COLLATERALISED BORROWING AND SECURITISATION

\begin{tabular}{|c|c|c|c|c|}
\hline \multirow[t]{2}{*}{ Panel A } & \multicolumn{4}{|c|}{ Loan Sale without Recourse } \\
\hline & $\begin{array}{c}\text { Initial } \\
\text { balances }\end{array}$ & \multicolumn{3}{|l|}{$\begin{array}{c}\text { Sells loans } \\
\text { without recourse }\end{array}$} \\
\hline \multicolumn{5}{|l|}{ Assets } \\
\hline Cash & 0 & 90 & & \\
\hline Loans & 100 & 0 & & \\
\hline \multicolumn{5}{|c|}{ Liabilities/Equity } \\
\hline Borrowings & 90 & 90 & & \\
\hline Capital & 10 & 0 & & \\
\hline Capital ratio & $10 \%$ & $0 \%$ & & \\
\hline \multirow[t]{2}{*}{ Panel B } & alised Borrov & & & \\
\hline & $\begin{array}{c}\text { Initial } \\
\text { balances }\end{array}$ & $\begin{array}{c}\text { Borrows using } \\
\text { loans as } \\
\text { collateral }\end{array}$ & $\begin{array}{l}\text { Lends cash } \\
\text { balance } \\
\text { to customers }\end{array}$ & $\begin{array}{c}\text { Borrows using } \\
\text { loans as } \\
\text { collateral }\end{array}$ \\
\hline \multicolumn{5}{|l|}{ Assets } \\
\hline Cash & 0 & 90 & 0 & 81 \\
\hline Loans & 100 & 100 & 190 & 190 \\
\hline \multicolumn{5}{|l|}{ Liabilities/Equity } \\
\hline Borrowings & 90 & 180 & 180 & 261 \\
\hline Capital & 10 & 10 & 10 & 10 \\
\hline Capital ratio & $10 \%$ & $5 \%$ & $5 \%$ & $4 \%$ \\
\hline
\end{tabular}


TABLE I : (CONTINUED)

\begin{tabular}{|c|c|c|c|c|}
\hline \multirow[t]{2}{*}{ Panel C } & \multicolumn{4}{|c|}{ Securitisation } \\
\hline & $\begin{array}{c}\text { Initial } \\
\text { balances }\end{array}$ & $\begin{array}{c}\text { Transfers loans } \\
\text { to SPV }\end{array}$ & $\begin{array}{l}\text { Lends cash } \\
\text { balance } \\
\text { to customers }\end{array}$ & $\begin{array}{l}\text { Transfers } \\
\text { loans } \\
\text { to SPV }\end{array}$ \\
\hline \multicolumn{5}{|l|}{ Assets } \\
\hline Cash & 0 & 90 & 0 & 81 \\
\hline Loans & 100 & $\mathrm{II}$ & 101 & 21 \\
\hline \multicolumn{5}{|l|}{ Liabilities/Equity } \\
\hline Borrowings & 90 & 90 & 90 & 90 \\
\hline Capital & 10 & 11 & 11 & 12 \\
\hline Capital ratio & $10 \%$ & $11 \%$ & $11 \%$ & $12 \%$ \\
\hline \multicolumn{5}{|c|}{ Comparing the Three Options } \\
\hline & $\begin{array}{c}\text { Initial } \\
\text { balances }\end{array}$ & $\begin{array}{c}\text { Loan sale } \\
\text { without recourse } \\
\text { (Panel A) }\end{array}$ & $\begin{array}{c}\text { Collateralised } \\
\text { borrowings } \\
\text { (Panel B) }\end{array}$ & $\begin{array}{l}\text { Securitisation } \\
\text { (Panel C) }\end{array}$ \\
\hline \multicolumn{5}{|l|}{ Assets } \\
\hline Cash & 0 & 90 & 81 & 81 \\
\hline Loans & 100 & 0 & 190 & 21 \\
\hline \multicolumn{5}{|l|}{ Liabilities/Equity } \\
\hline Borrowings & 90 & 90 & 261 & 90 \\
\hline Capital & 10 & 0 & 10 & 12 \\
\hline Capital ratio & $10 \%$ & $0 \%$ & $4 \%$ & $12 \%$ \\
\hline
\end{tabular}

In the case of non-recourse sale, shown in Panel A, the purchaser of the loan portfolio discounts its value, because it must accept the bank's representations about the borrowers' ability to repay and because the bank offers no recourse. In the example, the bank receives $€ 90$ for the portfolio it had carried at $€ 100$, and therefore recognises a $€ 10$ loss on the sale. The sale wipes out the bank's capital, causing alert regulators to shut the bank down, preventing it from making additional loans, and clarifying why banks avoid this alternative.

In the second alternative, shown in Panel B of Table 1, the bank borrows $€ 90$, secured against its $€ 100$ loan portfolio, raising its borrowing to $€ 180$. By overcollateralising the borrowing, the bank can obtain lower interest rates, but forgoes some principal. The bank can then lend the cash it has borrowed to homeowners, and can borrow against the new loans. Each round of borrowing, however, lowers the capital ratio. After the second round, the example bank is thinly capitalised, so vigilant regulators halt further replications of the strategy.

In Panel C of Table 1, the bank securitises the loan portfolio. The bank transfers the loan portfolio to an SPV, but it retains some interest. This interest may take the form of servicing rights on the loans to maintain the original contract with the homeowners, but generally also includes either an implicit or explicit risk position in the SPV. An explicit risk position, for example, would be to hold a lower-tier debt 
security of the SPV. An implicit risk position could be an unwritten understanding that the bank will ensure the payoffs of the SPV's securities, without which understanding the bank would have difficulty making future securitisations.

Under the securitisation arrangement shown in Panel C, the bank must record the fair value of its contractual retained interests, and here the magic of accounting comes into play. Because no organised market exists for the retained interests, the bank estimates their fair value and records that value on its balance sheet. This estimate, along with the cash received, determines the gain or loss on the transfer of the loan portfolio. In the example, the bank receives $€ 90$ from the SPV and values its retained interests at $€ 11$, yielding a $€ 1$ gain on the transfer. The values in this example are purely fictitious and, for the sake of displaying the accounting effects of different arrangements, the example holds constant the cash received for the loan portfolio across the three arrangements. The notion of an estimated value for retained interests that yields a securitisation gain does no violence to reality: unlike the simpler non-recourse sale transaction shown in Panel A, few securitisation transactions result in a loss for the originating entity at the time of the asset transfer.

The bank in Panel C has improved its capital ratio to 11 per cent, while at the same time accelerating the cash recovery from its loan portfolio. As long as regulators accept this accounting, the securitisation puts the bank in an excellent position for another round of lending and securitisation. Panel D compares the three options, showing securitisation as the clear winner, in terms of the bank's apparent capital ratio.

\section{HOW IS THIS POSSIBLE?}

The above-described 'magic of accounting' derives from two features of current accounting standards that enable banks to report gains when they transfer assets to SPVs. The first feature is an approach to valuation known as the financial components approach, under which the entity may value component parts of assets individually. An entity could, for example, value the stream of interest payments from the loan separately from the principal repayments, or value the 'servicing rights' on the loan separately from the primary cash flows. The financial components approach allows the entity to construct synthetic assets and liabilities, to replace the real underlying assets with the synthetic components, and to account for the components separately, including separate transfer or retention of individual components.

For this valuation approach to be conceptually valid the components themselves truly must be separate, that is, the risks and rewards of the various components must be independent of one another. Importantly, in most instances, the original assets remain unaltered by the securitisation. In our example, the households whose homes stand as collateral for and whose wages repay the mortgage loans generally see no change in the loan arrangements. The fundamental risks and rewards associated with a portfolio of loans, whether securitised or not, derives from those two things: the cash held or earned by the households, and the value of the homes as collateral; the degree of commonality of wages and of home values across the loans in the portfolio also plays a role. A valuation of synthetic components that ignores 
their connection to these underlying fundamentals, and their interrelatedness via the fundamentals, is conceptually flawed.

The second feature of accounting standards that facilitates securitisation's magical accounting qualities is so-called 'fair' valuation. Most accountants agree that assets trading regularly in liquid, public markets can be valued reliably and verifiably, and that investors have an interest in learning these current values for assets held by the entity, particularly when the assets' values have declined. Fair values for assets that do not trade, and particularly for assets that are not cleanly separable from other elements of the business, remain controversial. The lack of genuine, arm's length transactions to provide credible evidence makes fair values for such assets at best educated guesses, and at worst fiction.

In securitisation, the fair valuation of retained interests, a synthetic asset or liability which cannot trade by definition of the word 'retained', determines whether the originating bank recognises a gain or a loss when it transfers assets to its SPV. These educated guesses or fictional values therefore do not merely inform investors about assets held. In securitisations, they allow the bank to manufacture equity capital through recorded gains from opaque transactions.

With assistance from these two aspects of accounting, financial component valuation and fair valuation of non-traded assets, securitisation achieves a near-perfect triumph of form over substance. Banks accelerate cash flow from loans by having an SPV borrow against the loans, so that the bank's balance sheet does not appear more levered. At the same time, the banks transfer loans to the SPV without incurring losses, by judicious fair valuation of non-traded components. The SPV, having no business of its own except to issue securities based on assets transferred by a single originating bank, exists to make the bank's real leverage and risk position opaque.

\section{SELECTED ACADEMIC RESEARCH}

A few academics pointed out the hidden risk of securitisation transactions before the onset of the 2008-2009 crisis. They deserve credit for advocating an unfashionable position in an era when the risk may have appeared small. Rather than exhaustively review the literature, this summary discusses a small number of papers written prior to the crisis whose themes intersect with the topic at hand.

Rajan (2006) gives an excellent summary description of the costs and benefits of securitisation and other financial innovations. He describes 'hidden tail risks', i.e. risks of potentially catastrophic events that appear, based on limited history, to have extremely low probability. He also discusses the associated incentives for managers to create and retain such risks. So long as the bad event does not occur, managers can appear to generate impressive returns with little risk. He conjectures, with what now seems tremendous foresight, that many actors loading up on similar hidden tail risks could trigger systemic collapse.

The risk position in securitisation structures is precisely a hidden tail risk. The most secure cash flows from household mortgages are pledged to the safe tranches of the securitisation. The tail risk involves the joint event of the homeowner being unwilling or unable to meet the mortgage commitments and the home's collateral 
value falling below the amount owed, for many borrowers at once. As long as property values rise, the joint event does not happen and the risk remains hidden. Such conditions make it easier for banks to convince regulators that they can repeatedly sell loans profitably to SPVs, retaining no risk. The risk becomes apparent only when conditions turn adverse.

Niu and Richardson (2006), using US evidence from the period 1997-2003, demonstrate that SPV debt securities increase the originating entity's systematic risk, or $\beta$, in the same way as the originator's on-balance-sheet debt. Moreover, they find investors assess the securitisation gains as riskier or less sustainable when the originator has more outstanding securitised assets held in SPVs. These authors propose that securitisations involve 'implicit recourse' to the originator, making the transactions closer to secured borrowing than to true sales.

Landsman, Peasnell and Shakespeare (2008) studied a broad cross-section of US firms engaging in securitisation between 2000 and 2004. Their methods differed, but their objective was similar to that of Niu and Richardson (2006): to determine whether securitisations constitute true asset sales or secured borrowing. They show that investors value originating entities as if they continue to own the SPV's assets and liabilities; hence the investors treat securitisations as secured borrowing by the originator.

Using detailed data on individual securitisations by US banks from the period 2001-2006, Chen, Liu and Ryan (2008) distinguish between securitisations treated as sales of unique portfolios, such as those described in this paper's example, and revolving arrangements such as credit card securitisations. In the latter, the originator typically provides explicit recourse via contractual arrangements that accelerate payouts for underperforming assets. In the former type, these authors demonstrate that originators retain highly concentrated risk in 'first-loss' components.

The research cited above shows that some observers in the academic and investing communities found securitisation accounting lacking, even before the financial crisis. They confirm that treating securitisations as sales of individual components fails to reflect the risks and rewards retained by the entity.

\section{SHOULD IRELAND CARE?}

All of the academic papers cited above use US data to make their points, and arguably the securitisation aspect of the crisis was isolated there. Why, then, should Ireland care about securitisation? To answer this question, Figure 3 employs data produced by the Central Bank and Financial Services Authority of Ireland. ${ }^{2}$

Figure 3 displays, for the period January 2003 through February 2010, the supply of credit by Irish banks (financial institutions excluding credit unions that are resident in Ireland) to Irish households. The black dashed line at the top of the graph shows the amount of credit held on the banks' balance sheets in billions of euro, as shown on the left-hand vertical axis. This line traces the credit expansion during the early part of the decade, until mid-2008, when the supply of credit apparently shrinks. The grey solid line closer to the bottom of the graph displays the amount of credit held in securitisation SPVs, also stated in billions of euro. The bar graph 
FIGURE 3: SUPPLY OF CREDIT TO IRISH HOUSEHOLDS FROM IRISH BANKS

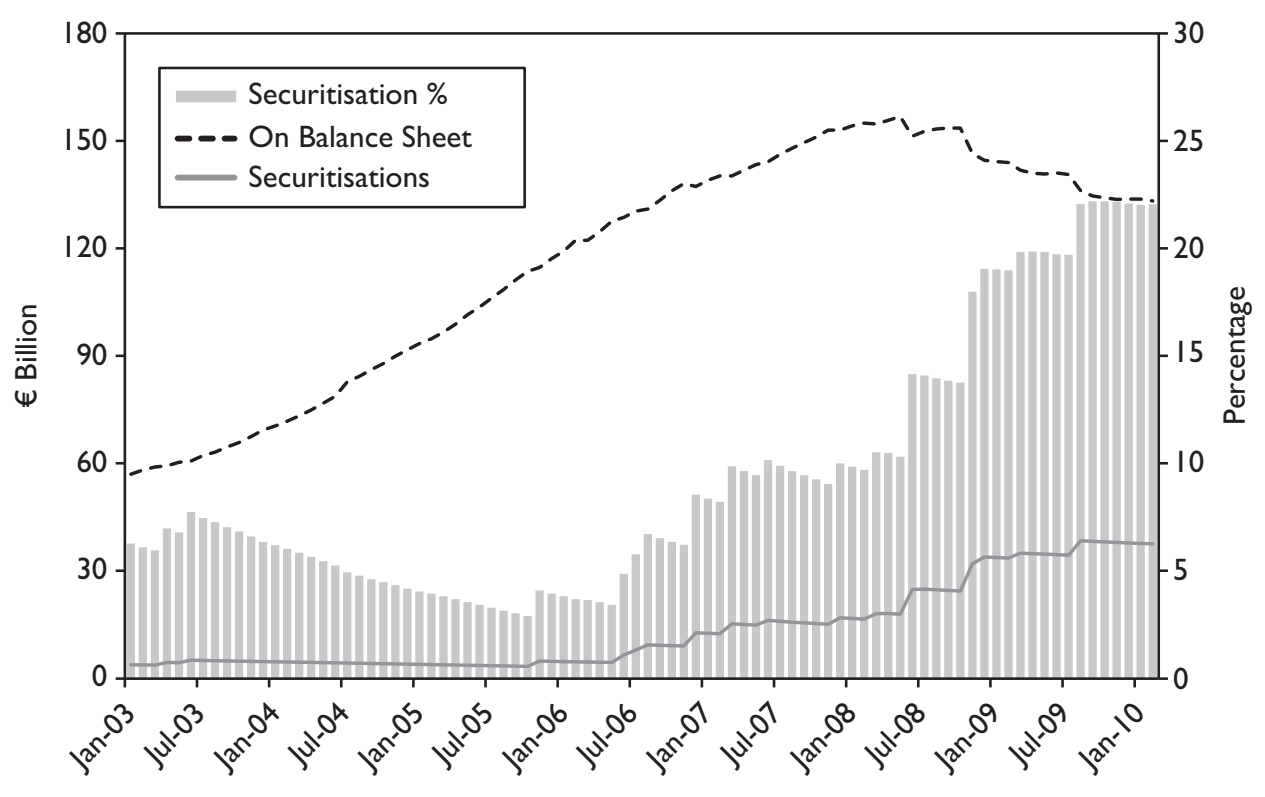

Data source: Central Bank and Financial Services Authority of Ireland

that forms a background to the line graph shows the proportion that securitisations form of the total Irish supply of credit to households, that is, the amount in SPVs divided by the sum of the SPV amount and the on-balance-sheet amount. The scale for the bar graph is on the right-hand vertical axis.

Figure 3 shows that the amount of household credit held in securitisations remained at 10 per cent or less until early 2007. Beginning in mid-2006, we see an expansion in Irish banks' use of securitisation, continuing through the crisis. By late 2009 and continuing into early 2010, Irish banks held about 22 per cent of household credit off balance sheet in securitisation vehicles. Thus, though securitisation may not have been a large factor before the crisis, it is a substantial and apparently growing feature of Irish banks' activities.

We cannot tell from these data who holds the securities issued by the SPV, nor which banks are most heavily involved as originators. Because the SPVs qualify as separate entities by design, sponsoring banks would not disclose the capital structure of these separate entities. Nor can we tell, bank by bank, the amount of assets held in securitisation vehicles, because of the paucity of disclosure once the assets are securitised. The transactions are designed for, and achieve, opacity.

\section{WHERE ARE THE MONITORS?}

Academics, journalists and pundits have spilled oceans of ink describing failures by many parties who should have played monitoring roles to prevent the financial 
collapse of 2008-2009. ${ }^{3}$ For the accounting issues raised here, the most relevant potential monitors are financial reporting auditors and standard-setters, and bank auditors and regulators. Auditors ensure the entity has complied with the reporting standards or banking regulations. Securitisations, however, are structured precisely to conform to existing accounting standards and banking regulations, and to leave no role for an auditor's judgement to impose different accounting. Culpability, if any, therefore moves up to the level of the standard-setters and regulators. At this level, the monitors play a cat-and-mouse game against bankers, lawyers and accountants determined to write contracts that achieve the desired degree of opacity.

Consider, for example, US Financial Accounting Standards Board (FASB) Interpretation No. 46 (FIN46) (Financial Accounting Standards Board, 2003). To achieve the financial statement benefits of securitisation shown in Panel C of Table 1, companies must create their SPVs to appear independent. The favourable financial statement appearance would be undone if the originator were forced to consolidate the SPV; in that case the company would appear as in Panel B of Table 1, collateralised borrowing. Prior to 2003, accounting standards held that voting interests determined control and therefore consolidation. Companies exploited this to create SPVs in which the originating entity did not have majority voting control of the SPV's common equity, but nonetheless retained substantial financial and decisionmaking interest. Rather than abandoning the financial components approach, the FASB aimed to curtail this practice with FIN46, by broadening the criteria for consolidation to include the apportionment of risks and benefits.

FIN46 required originators to consolidate existing SPVs that met its criteria immediately, and to consolidate any future SPVs meeting its criteria from their inception. It is not difficult to predict the response by originating financial institutions: as quickly as possible, they wound up any SPVs that FIN46 required them to consolidate, designed new SPVs to miss the consolidation triggers set by the new interpretation, and continued their off-balance-sheet financing. ${ }^{4}$ The standardsetters' role becomes one of trying to close loopholes without creating new ones, while companies intent on maintaining their off-balance-sheet activity seek to stay one step ahead of the standard-setters.

Banking regulators showed no apparent concern that securitisation might hide risk during this period. During the crisis, Irish banks adopted the Basel II framework, under which a bank can develop its own internal model of credit risk exposure and, if approved, use its model to compute its capital requirements. A look at the financial statements of two large Irish banks, Allied Irish Banks and Bank of Ireland, reveals that both reported higher core, Tier 1, and total capital measured at the same point in time under Basel II as compared with Basel I. ${ }^{5}$ This suggests that their models discovered no 'hidden tail risk.'

\section{CONCLUDING REMARKS}

This paper hopes to convey that the current accounting for securitisations obscures the risks retained by the originating entity. By allowing companies to account 
piecemeal for synthetic components, rather than for entire contracts, accounting allows substantial financing activity to slip off balance sheet. By further allowing fair values on non-traded components to determine valuations, accounting allows originators to manufacture equity capital.

The academic research on the topic shows that investors treat securitised assets as if they continue to belong to the originating entity, and treat the securitisation debt as the originator's debt. A potential solution would be to return to the prefinancial-components practice of accounting for entire contracts, not for synthetic components. If a bank retains an interest in a loan, then accounting should not record the loan as transferred, and should record securities issued against it as secured borrowing. This all-or-nothing approach, widely dismissed as obsolete before the financial crisis, has at least the benefit of making the arrangement transparent.

Despite claims that securitisation played a relatively minor role in Irish banks' activities prior to the crisis, the evidence suggests that Irish banks have increasingly used this form of financing since 2007. In one respect, this is unsurprising, given securitisation's useful financial statement effects of accelerating cash flow without (apparently) increasing leverage, Irish banks' need to appear better capitalised, and securitisation's acceptance by bank regulators. On the other hand, securitisation's proven ability to mask risk is a cause for concern.

\section{ENDNOTES}

1 I thank Joseph Cheng and Deanna Qi for capable research assistance, and Catalina Anghel for helpful comments. I am grateful for financial support from the Ernst \& Young Professorship at the University of Waterloo, and from the Social Sciences and Humanities Research Council of Canada. This paper is based on a plenary address delivered at the Irish Accounting and Finance Association meetings in Belfast during May 2010, and therefore reflects events up to spring 2010. I thank Ann-Marie Ward for suggesting the topic and for providing helpful links to data, and the editors of the Irish Accounting Review for encouraging me to write up my remarks. I am solely responsible for errors and omissions.

2 http://www.centralbank.ie/polstats/stats/cmab/documents/ie_table_a.6_loans_to_irish_residents_-_ outstanding_amounts_(incl._securitised_loans).xls, accessed 13 April 2010.

3 See, for example, White (2009) on credit rating agencies and financial regulators, Jorion and Zhang (2009) on counterparty risk, Ojo (2009) on bank regulators and Barth and Landsman (2010) on financial reporting. See, for example, General Electric Corporation's 2003 Annual Report at note 29.

$5 \quad$ See Allied Irish Banks' Annual Financial Report 2008 at p. 34, and Bank of Ireland's Report \& Accounts for the year ended 31 March 2008 at p. 5.

\section{REFERENCES}

Acharya, V., Cooley, T., Richardson, M. and Walter, I. (2009). Manufacturing Tail Risk: A Perspective on the Financial Crisis of 2007-09, Foundations and Trends in Finance, Vol. 4, No. 4, pp. 247-325.

Barth, M.E. and Landsman, W.R. (2010). How Did Financial Reporting Contribute to the Financial Crisis?, European Accounting Review, Vol. 19, No. 3, pp. 399-423.

Chen, W., Liu, C. and Ryan, S.G. (2008). Characteristics of Securitizations that Determine Issuers' Retention of the Risks of the Securitized Assets, The Accounting Review, Vol. 83, No. 5, pp. 1181-1215. 
O’Brien

Connor, G., Flavin, T. and O'Kelly, B. (2010). The US and Irish Credit Crises: Their Distinctive Differences and Common Features, working paper, 8 March 2010, available from: <http:/ / ssrn.com/abstract=1566844>, accessed 10 March 2010.

Financial Accounting Standards Board (2003). Consolidation of Variable Interest Entities: An Interpretation of ARB No. 51, FASB Interpretation No. 46, Norwalk, CT: Financial Accounting Standards Board.

Jorion, P. and Zhang, G. (2009). Credit Contagion from Counterparty Risk, Journal of Finance, Vol. 64, No. 5, pp. 2053-2087.

Kormendi, R.C., Bernard, V.L., Pirrong, S.C. and Snyder, E.A. (1989). The Origins and Resolution of the Thrift Crisis, Journal of Applied Corporate Finance, Vol. 2, No. 3, pp. 85-99.

Landsman, W.R., Peasnell, K.V. and Shakespeare, C. (2008). Are Asset Securitizations Sales or Loans?, The Accounting Review, Vol. 83, No. 5, pp. 1251-1272.

Loutskina, E. and Strahan, P.E. (2011). Informed and Uninformed Investment in Housing: The Downside of Diversification, Review of Financial Studies, Vol. 24, No. 5, pp. 1447-1480.

Niu, F.F. and Richardson, G.D. (2006). Are Securitizations in Substance Sales or Secured Borrowings? Capital Market Evidence, Contemporary Accounting Research, Vol. 23, No. 4, pp. 1105-1133.

Ojo, M. (2009). Basel II and the Capital Requirements Directive: Responding to the 2008/09 Financial Crisis, working paper, 18 September 2009, available from: <http://ssrn.com/ abstract=1475189>, accessed 31 May 2011.

Rajan, R.G. (2006). Has Finance Made the World Riskier?, European Financial Management, Vol. 12, No. 4, pp. 499-533.

White, L.J. (2009). The Credit Rating Agencies: Understanding their Central Role in the SubPrime Debacle of 2007-2008, Critical Review, Vol. 21, Nos. 2-3, pp. 389-399. 